discussion papers

FS IV $02-35$

Market Conduct and Endogenous

Lobbying: Evidence from the U.S. Mobile

Telecommunications Industry

Tomaso Duso *

Astrid Jung **

* Humboldt University, Berlin

** WZB - Wissenschaftszentrum Berlin

December 2002

ISSN Nr. 0722 - 6748

Forschungsschwerpunkt

Markt und politische Ökonomie

Research Area

Markets and Political Economy 
Zitierweise/Citation:

Tomaso Duso and Astrid Jung, Market Conduct and

Endogenous Lobbying: Evidence from the U.S. Mobile

Telecommunications Industry, Discussion Paper

FS IV 02-35, Wissenschaftszentrum Berlin, 2002.

Wissenschaftszentrum Berlin für Sozialforschung gGmbH,

Reichpietschufer 50, 10785 Berlin, Germany, Tel. (030) $25491-0$

Internet: www.wZ-berlin.de 


\section{ABSTRACT \\ Market Conduct and Endogenous Lobbying: Evidence from the U.S. Mobile Telecommunications Industry*}

by Tomaso Duso and Astrid Jung

This paper empirically explores the relationship between firms' market behavior and their lobbying activities in a regulated market. In particular, we investigate whether the amount of contributions offered by cellular service providers to fund the campaigns of political parties affected market conduct in the early US mobile telecommunications industry. We structurally estimate market interactions while taking the potential endogeneity of lobbying decisions into account. Our results show that competition was more intense in those states where campaign contributions by the cellular industry have been higher. Furthermore, we reject the hypothesis that lobbying activities can be regarded as exogenous in the study of market conduct.

Keywords: Lobbying, Campaign Contributions, Conjectural Variations, Mobile Telecommunications, U.S.

JEL Classification: D72, L13, L51, L96, C31

* We are particularly grateful to Johan Lagerlöf for many useful discussions. We also thank Jesús Crespo-Cuaresma, Jean-Pierre Florens, Paul Heidhues, Marc Ivaldi, Kai Konrad, Lars-Hendrik Röller, Ralph Siebert, Aico van Vuuren, Christine Zulehner, as well as seminar and conference participants at the WZB, IDEI in Toulouse, University of Vienna, Erasmus University Rotterdam, SMYE 2002, EARIE 2002, and ECARES-CEPR 2002 for their helpful comments. Both authors gratefully acknowledge partial financial support from the German Science Foundation (DFG) grant number Ro 2080/4. We retain the sole responsibility for remaining errors.

Corresponding author. Tomaso Duso, Department of Economics at BWZ, University of Vienna, Bruennerstraße 72, A-1210 Vienna, Austria. Tel.: +43 1 4277-37462 E-mail: tomaso.duso@univie.ac.at. 


\section{Marktverhalten und Endogenes Lobbying: Empirische Evidenz für die} Mobilfunkindustrie der USA

Im diesem Beitrag wird der Zusammenhang zwischen dem Unternehmensverhalten in einem regulierten Produktmarkt und Lobbying-Aktivitäten empirisch untersucht. Insbesondere analysieren wir, ob die für Wahlkampagnezwecke ausgegebenen Parteispenden von US-amerikanischen Mobilfunkunternehmen Ende der achtziger Jahre einen Einfluss auf das Markverhalten hatten. Wir schätzen ein strukturiertes Produktmarktmodell unter Berücksichtigung der potentiellen Endogenität der Lobbying-Aktivitäten. Unsere Analyse zeigt, dass der Produktmarktwettbewerb in denjenigen U.S. Staaten intensiver war, in denen die Mobilfunkunternehmen höhere Parteispenden leisteten. Des Weiteren wird die Hypothese, dass die LobbyingAktivitäten exogen gegenüber dem Marktverhalten sind, statistisch abgelehnt. 


\section{Introduction}

Industrial economists have traditionally concentrated on the study of product market behavior, while abstracting from activities that firms undertake to favorably influence their business environment. Many product markets are, however, subject to governmental intervention. Therefore, individual companies or the industry as a whole have an interest to interfere in the policy making process. One way to achieve political influence is to invest money and resources in order to get the attention of politicians and regulators, gain their goodwill, and inform them about issues at stake. The extent to which firms coordinate such lobbying activities to maximize the benefit of the whole industry is likely to alter their willingness to abide by collusive agreements in the product market. Hence, ignoring lobbying might bias our assessment of competition.

This paper empirically explores the relationship between market behavior and lobbying activities in a regulated market. In particular, we investigate how the amount of firms' contributions to political parties influences their product market conduct. Furthermore, we test whether lobbying decisions are endogenous with respect to market strategies.

Our analysis employs data from the U.S. mobile telecommunications industry during its early development phase in the second half of the 1980's. Being divided into many small geographical markets, which are exposed to varying forms of state specific price regulation, this industry is uniquely suited for investigating the interrelation between market outcomes and the political arena.

Lobbying efforts encompass a variety of firms' strategies, many of which are difficult to quantify and often unobservable. In the United States, political campaign contributions by individual companies and industrial interest groups are widespread and have the advantage of being publicly disclosed. Therefore, we apply campaign contributions as a measure for lobbying and interpret them as a way cellular operators acquire access to politicians. ${ }^{1}$ In return for the campaign financing politicians may adjust price regulation rules and exert influence on the composition and activities of the regulatory body, the

\footnotetext{
${ }^{1}$ Ansolabehre et.al. (2002) find a strong positive association between expenses by registered lobbyists and PAC (Public Action Committee) contributions.
} 
Public Utility Commission (PUC). However, there exist other aspects of governmental intervention, such as restrictions on the placement of cellular antennas, which give a rationale for rent seeking activities in this industry and are equally consistent with our analysis. We abstract from attempts to influence entry regulation, because the market structure of the U.S. mobile telecommunications industry was settled at the federal level on a long-run basis before the sample period. ${ }^{2}$

Our empirical model of the cellular industry follows a structural approach, where firms' market conduct is estimated by specifying market demand and the industry supply derived in a Cournot game. We then explore the influence campaign contributions have on the estimated conjectural variations parameter. The potential endogeneity of lobbying is accounted for in a descriptive way rather than by estimating a lobbying supply function. Thereby we avoid untestable assumptions about the complex underlying economic model of the lobbying process.

This paper yields two empirical results: First, we find evidence that product market strategies and lobbying activities are indeed simultaneous and interdependent decisions. Hence, firms' attempt to influence their business environment should not be ignored when studying market behavior in the early U.S. cellular industry. Second, our estimations reveal a negative and significant impact of endogenized campaign contributions on firms' conduct: high contributions tend to destabilize collusion.

Our interpretation of the negative link between lobbying expenditures and collusion is based on the theoretical literature concerning the relationship between coordination of firms in different dimensions on the one hand, and, on the other, on how lobbying coordination affects actual lobbying expenditures. Applying the theory of multimarket contact (Bernheim and Whinston, 1990) to the interrelation between coordination in the product market and in lobbying, we expect that any individual deviation from the collectively optimal lobbying contributions would not only be punished by returning to the one-shot political equilibrium, but also by abandoning cooperation in the product market.

\footnotetext{
${ }^{2}$ For a rent seeking analysis of the licensing process in the U.S. cellular industry see Hazlett and Michaels (1993).
} 
Thus, as long as market cooperation itself is sustainable, it might help to deter defection in the lobbying game. This argument implies a positive relationship between product market collusion and coordination in lobbying formation. Ludema (2001) qualifies the multimarket argument by showing that, in cases where defection in individual lobbying contributions are observed significantly lagged, collectively optimal lobbying efforts for public-good type regulation may actually destabilize market cooperation. ${ }^{3}$

The second theoretical aspect which is important for the interpretation of our finding addresses the relationship between coordination in the political market and actual lobbying expenditures. The political economy literature has analyzed this point differentiating two cases. If lobbying is for a pure public good, an increase in coordination among firms leads to higher contributions. When, in contrast, a specific type of regulation hurts some firms while benefiting others, lobbying is aimed at acquiring a private good. In this case, improved coordination between competing interests diminishes aggregated lobbying efforts. $^{4}$

In light of this literature the negative impact of lobbying expenditures has two possible interpretations: Either, if cooperation at different levels of firms' activities are complementary, the policy decisions are considered to be a private good among the firms of the cellular industry. Or, when lagged observability of defection in the lobbying process results in cooperation at both levels being substitutes, policy is a public good. The latter interpretation hinges, however, on the informational lag being sufficiently large.

The empirical point of this paper, that the degree of product market competition

\footnotetext{
${ }^{3}$ The reason for this is that the profit increase due to a favorable policy is greater for those agents who deviate from coordination in the political market, because the others bear the cost of lobbying and cannot react immediately to defection in lobbying. Ludemas paper differs from (Bernheim and Whinston 1990) in that he adjusts the model to the analysis of the connection between lobbying and the product market, where the coordination in one market (lobbying) alters the gains from collusion in the other (the product market). The potential negative association between coordination in the two dimensions relies, however, on the observability lag.

${ }^{4} \mathrm{~A}$ general insight from the rent seeking literature is that total lobbying expenditures increase with the number of competing individuals or groups (see Nitzan, 1994). This holds even if we take into account that, within a group of coordinated firms, the rent has the character of a public good (Katz et al. 1990). Since improved coordination among rent seekers can be interpreted as a decline in the number of competing parties, it triggers a drop of rent seeking efforts. A similar result is derived by Bernheim and Whinston (1986) for menu auctions: Firms that manage to align their interests on policy choices limit the politicians' ability to extract rents.
} 
depends on firms' endogenously determined lobbying activities, is a strong point in favor of including firms' incentives to shape their business environment in the study of competition in regulated industries. A number of recent papers (Besley and Case, 2000; Duso and Röller, 2003; and Duso, 2002) indicate the importance of the endogeneity of regulation for the assessment of market outcomes but do not identify the sources of such an endogeneity. Our paper suggests that lobbying is such a source, because it is found to be endogenous with respect to the product market.

This paper is an empirical counterpart to a growing theoretical literature, which explicitly models the link between firms' behavior in the product market and their activities along other dimensions, specifically, lobbying for regulation. Baron (1999) is the first to provide a formal static model where market strategies are integrated with their political actions, but he ignores cooperation among firms. Damania and Fredriksson (2000) and (2002) show that firms incentive to form a lobby group in order to influence environmental regulation crucially depends on the industry's ability to collude in the product market as well as on collusive profits.

In this paper we use the same market data as Parker and Röller (1997) who find that prices in the cellular industry were, on average, significantly above the noncooperative duopoly level and that conduct depended on exogenous product market characteristics, such as multimarket contact $^{5}$ and cross ownership.

The paper proceeds as follows. Section 2 briefly describes the U.S. cellular market and the data. In section 3 we develop a structural model of market interactions and present our empirical specification considering lobbying as exogenous. In section 4 we endogenize lobbying. Section 5 discusses the empirical findings, and we conclude in section 6 .

\footnotetext{
${ }^{5}$ Note that, in their paper, the term "multimarket" indicates that firms meet in several product markets. In our paper we apply this concept to the relation between the product market and the political arena.
} 


\section{The Data}

The regulatory and market environment in the U.S. cellular industry in the second half of the 1980's are unique and constitute an excellent natural experiment for analyzing the relationship between lobbying and competition. On the one hand, we observe, for production as well as political decisions, many geographically separated markets within a single industry (for the former, the Metropolitan Statistical Areas and for the latter, the states). This fact guarantees enough heterogeneity - in the sense of statistical variation

- to investigate the empirical interrelation between market-level collusion and state-level lobbying.

On the other hand, the product market is homogeneous, which justifies the same functional specification for the demand and first order condition across markets. Moreover, because of the homogeneity of the institutional environment across U.S. states, unobserved heterogeneity in the estimation of the lobbying equation is minimized.

Another important characteristic of the U.S. mobile telecommunications industry is that the market structure was exogenously determined during the entire sample period. Each of the considered markets started in the middle of the 1980's as a monopoly and was subsequently opened up to a second firm. This peculiarity allows us to concentrate on market conduct in a specified market structure and to rule out more complex games, where firms make their production decisions under the pressure of potential entry.

The database that we use is remarkably rich and covers the sample period 1985-1988. It contains product market variables such as prices, output, demand, cost, and market structure variables and information about the regulatory and political environments, such as the structure of the regulatory body and the composition of the states' governments and legislatures. Furthermore, it provides data on firms' political activities measured by their campaign contributions to political parties.

Part of the data has been already exploited in other studies. The market data were collected and used by Parker and Röller (1997), and we aggregated them to yearly ob- 
servations in order to match the lobbying data. ${ }^{6}$ The political data originates form the Book of the States and from the U.S. Statistical Abstract. The data on political contributions were kindly provided by the Center of Responsive Politics that elaborates figures stemming from the Federal Election Commission. ${ }^{7}$

Table 1 reports a brief description of the variables used in this study, whereas tables 2 and 3 contain the preliminary statistics. The first column of table 2 refers to the full sample, in which observations do not follow a specific periodicity. The aggregated sample represented in the second column of the table denotes the average observation for a given year calculated to match the market variables to the lobbying data, which is observed on a yearly basis. As a result the new market data contains one to four yearly observations for each of the considered 122 metropolitan markets. The differences in the mean and standard errors of the variables between the two samples are very small and not statistically significant.

Apart from market price $(\mathrm{P})$ and quantity $(\mathrm{Q}),{ }^{8}$ we have information on demand shifters like the market population (POP), annual income per capita (INCOME), population density (DENSITY), and the number of high potential business establishments (BUSINESS). The data on cost shifters include the cost of energy (ENERGY), office and operation costs (RENT and OPERATE), labor costs in the cellular industry (WAGE), and cost of capital (PRIME). Dummies equal to one indicate duopoly periods (ENTRY) and markets that were subject to any form of price regulation (REGULATION).

In table 3 we report statistics for the political variables, which constitute a balanced

\footnotetext{
${ }^{6}$ The market data originate from many different sources, such as Cellular Price and Marketing Letter, Information Enterprise, Cellular Business, Cellular Market Data Book, EMCI, BOMA Experience Exchange Report, U.S. Department of Energy, U.S. Department of Labor, Bureau of Labor Statistics, U.S. Department of commerce, and Bureau of Census. We refer the interested reader to Parker and Röller (1997) for a more precise description of the market data. We are very grateful to Phil Parker and Lars-Hendrik Röller for allowing us to use their data.

${ }^{7}$ In particular, we thank Douglas Weber from the Center for Responsive Politics for making available the unpublished data on political contributions for our sample period.

${ }^{8}$ The price of a singular cellular operator is defined as the monthly bill paid by a costumer for 500 minutes of usage, assuming that he chooses the least expensive among the different plans offered. Since output levels are not directly observable, the quantity is proxied by the number of cellular antenna sites used by operators. Parker and Röller calculated from a sub-sample with available output measures a correlation index between the number of antennas and the number of subscribers equal to 0.92 ( $\mathrm{p}$-value $<0.0001)$.
} 
panel with four yearly observations for each of the 40 states included in our sample. The information covers the composition of the different states' legislature and executive: a dummy equal to one if the governor came from the democratic party (GOVDEM), and the governor's salary (GSALARY). Variables related to the regulatory body are the Public Utility Commission's number of board members (PUCMEM), the length of their office (PUCTERM), their salary (PUCSALARY), and the number of full-time employees (PUCSTAFF). Indicators for election years (PRESELECT, FEDELECT, LEGISELECT) and for how close the state-level election results of the parties were to each other (TIGHT) are also included in the data set. Other potential controls for the lobbying process are the population of the state (POPSTATE) and its average income (INCSTATE). Finally, lobbying (LOBBY) represents the yearly aggregated campaign contributions from cellular firms operating in a state to candidates of that state who campaign in federal elections.

All political variables lag one year with respect to the market and lobbying data because a newly elected government needs some time before being able to implement policy changes.

\section{Market Conduct and Exogenous Lobbying}

In this section, we explicitly model firms' interactions in the product market adopting an established tool in industrial organization: the conjectural variations approach. We specify and estimate an oligopoly model at the industry level (see Bresnahan 1989), which enables us to identify firms' conduct in the market place through the simultaneous estimation of a demand function and the first order condition for profit maximization. We then study how firms' lobbying activities, which in this first step are assumed to be exogenous, influence firms' market behavior.

The structural market model we apply was already specified and estimated by Parker and Röller (1997). Let the inverse market demand be: ${ }^{9}$

$$
P_{m s}=P\left(Q_{m s}, X_{m s}^{D}\right) .
$$

\footnotetext{
${ }^{9}$ Our estimations abstract from time effects in the residuals, because the panel is too short and too unbalanced. Therefore we omit time subscripts throughout.
} 
The price for cellular services $P_{m s}$, in market $m$ within state $s$ depends on the market production $Q_{m s}$ and on a set of market specific demand shifters $X_{m s}^{D}$. We assume that the firm $i$ 's variable costs $C\left(Q_{i m s}, X_{m s}^{C}\right)$ are a function of its output $Q_{i m s}$ and of a set of exogenous market-specific cost shifters $X_{m s}^{C}$. Each firm maximizes its profits with respect to the produced quantity. We let the cost structure and conduct among firms be symmetric, which, in homogeneous good industries, implies that each firm chooses the same output level $Q_{i m s}=Q_{j m s}=Q_{m s} / N_{m s}$, where $N_{m s}$ is the number of firms. Hence the optimality condition at the market level obtained by summing the individual first order conditions over the $N_{m s}$ firms is:

$$
\theta_{m s} \frac{\partial P(\cdot)}{\partial Q_{m s}} Q_{m s}+P(\cdot)-M C\left(\frac{Q_{m s}}{N_{m s}}, X_{m s}^{C}\right)=0
$$

where $M C(\cdot)$ denotes the marginal cost function.

Equation (2) allows us to estimate market conduct using market data instead of firmlevel data. The conjectural variation, or conduct parameter $\theta_{m s}$ measures the degree of market competitiveness. If, in statistical sense, $\theta_{m s}=0$, the market is perfectly competitive; if $\theta_{m s}=1 / N_{m s}$, firms behave as Cournot-Nash competitors; and if $\theta_{m s}=1$, then conduct is consistent with a monopoly or cartel.

We assume that the conjectural variation $\theta_{m s}$ is not constant but rather a market specific varying parameter: ${ }^{10}$

$$
\theta_{m s}=\theta\left(L_{s}, E N T R Y_{m s}\right)
$$

where $L_{s}$ are the total lobbying expenditures by mobile telecommunications firms, as measured by their campaign contributions to political parties, and $E N T R Y_{m s}$ is a dummy variable equal to 1 when the second carrier entered the market. Specifying $\theta_{m s}$ as a non-constant parameter is a convenient way of addressing the relationship between the agents' behavior in the product market and in the political process without employing a full structural model about the choice of regulation, its influence on profits and campaign contributions at hand.

\footnotetext{
${ }^{10}$ See Mayo and Otsuka (1991) and Parker and Röller (1997) for the estimation of a varying conduct parameter.
} 
The implementation of the above model involves the empirical specification of two simultaneous equations (1), (2), and the varying conduct parameter (3). Following Parker and Röller (1997), we choose a semilogarithmic specification for the inverse demand:

$$
\begin{aligned}
P_{m s}= & b_{0}+b_{1} \log \left(Q_{m s}\right)+b_{2} \text { POP }_{m s}+b_{3} \text { BUSINESS } \\
& +b_{4} \text { INCOME } E_{m s}+b_{5} \text { DENSITY } Y_{m s}+b_{6} \text { YEAR }_{m s}+\epsilon_{m s}
\end{aligned}
$$

where $\epsilon_{m s}$ is an i.i.d. stochastic term. Marginal costs are approximated as a linear function in quantity and the cost shifters: ${ }^{11}$

$$
\begin{aligned}
M C_{i m s}= & a_{0}+a_{1} \frac{Q_{m s}}{1+E N T R Y_{m s}}+a_{2} E N E R G Y_{m s}+a_{3} W A G E_{m s} \\
& +a_{4} \operatorname{RENT}_{m s}+a_{5} Y E A R_{m s} .
\end{aligned}
$$

As we have $\partial P_{m s} / \partial Q_{m s}=b_{1} / Q_{m s}$ due to the semilogarithmic specification of the inverse demand function, the empirical version of the firms behavior (2) reduces to:

$$
P_{m s}=M C_{m s}-b_{1} \theta_{m s}+\nu_{m s}
$$

where $\nu_{m s}$ is an i.i.d. error.

For the sake of identification and in order to account for the influence of market structure on conduct, we allow the conduct parameter to vary across monopoly and duopoly periods. Furthermore, we use the information gathered by this unique market structure to perform a specification test proposed by Parker and Röller (1997). If our model is correctly specified, it should, during monopoly periods, predict monopoly behavior, i.e. a conduct parameter equal to one. For these periods and for the functional forms assumed in (4) and (5), we could not reject the null hypothesis $\theta_{m s}=1$ at the $5 \%$ confidence level. $^{12}$ This result confirms our demand and cost specification.

In order to increase the efficiency of our estimates, we impose $\theta_{m s}=1$ for monopoly periods. For duopoly periods, we assume that the conduct parameter is a function of

\footnotetext{
${ }^{11}$ Intuition might suggest that there are economies of density in the provision of cellular services, because antennas can be used more efficiently in densely populated areas. In this paper DENSITY is excluded from the cost shifters, because quantity is proxied by the number of antennas and we would not expect the costs of an additional antenna to decrease in population density. We also eliminated PRIME and OPERATE, since they are highly correlated with YEAR and RENT.

${ }^{12}$ In order to fully exploit the available information, the test was carried out using the original, nonaggregated data.
} 
lobbying expenditures that, at this stage, are taken to be exogenous:

$$
\theta_{m s}= \begin{cases}1 & \text { if monopoly } \\ \frac{1}{1+\exp \left(-\widetilde{\theta}_{m s}\right)} & \text { if duopoly }\end{cases}
$$

where $\widetilde{\theta}_{m s}=d_{0}+d_{1} L O B B Y_{s}$. The functional form ensures that the conduct parameter is estimated within its theoretical bounds, while preserving a strictly monotonic transformation of $\widetilde{\theta}_{m s}$ to $\theta_{m s}$.

We also impose the second order condition for a profit maximum: ${ }^{13}$

$$
b_{1}=\frac{a_{1} Q_{m s}}{\theta_{m s}\left(1+E N T R Y_{m s}\right)\left(2-\theta_{m s}\right)}-\exp (e) .
$$

The empirical implementation of the model developed in this section implies the simultaneous estimation of equations (4) and (6), with the second order condition (8) and the varying conduct parameter (7).

\section{Endogenous Lobbying}

Firms anticipate the impact of their lobbying expenditures on regulation, which eventually affects the product market. Therefore, they take their product market strategy into account when deciding about lobbying expenditures and vice versa. This argument suggests that lobbying expenditures are endogenous. Estimating the above exogenous lobbying model results in inconsistent estimates of the impact lobbying has on market conduct. In this section, we extend the previous model in order to account for the potential endogeneity of lobbying expenditures.

Lacking a comprehensive economic model that interrelates lobbying expenditures, potentially multidimensional regulatory decisions, and the product market game, we estimate a flexible descriptive rather than a structural lobbying equation. The exogenous variables it contains are selected on the basis of the theoretical literature discussed above. The key idea is that lobbying expenditures depend on firms' ability to coordinate in

\footnotetext{
${ }^{13}$ Equation (8) is the empirical implementation of the second order condition derived by differentiating equation (2) with respect to the total market quantity $Q_{m s}$.
} 
the political market. Therefore, we consider as explanatory variables those characteristics that can be expected to influence firms' incentives and ability to coordinate their lobbying activities.

First, we control for the impact of future market profitability - as expressed by the state's population and per capita income - on lobbying expenditures, because firms' incentive to lobby for a favorable regulatory environment increases with the benefits which can be gained in such an environment. Second, regulatory and political factors are taken into account, since these shape firms' ability to lobby and the cost to effectively influence the policy maker. Therefore, we control for governments' characteristics as well as the structure of the state regulatory body. Also, we consider the impact of the regulatory regime on campaign contributions, since it is crucial to those regulatory issues that firms want to address. Finally, we control for the number of firms acting in the state, because it affect firms' ability to coordinate their rent seeking efforts. ${ }^{14}$

Our empirical specification of the lobbying equation is a linear combination of the discussed exogenous variables:

$$
L O B B Y_{s}=c_{0}+\Pi_{s} \mathbf{c}_{\mathbf{1}}+G_{s} \mathbf{c}_{\mathbf{2}}+R_{s} \mathbf{c}_{\mathbf{3}}+c_{4} \text { REGULATION }{ }_{s}+c_{4} \text { SFIRM }_{s}+\eta_{s},
$$

where $\mathbf{c}_{\mathbf{1}}, \mathbf{c}_{\mathbf{2}}, \mathbf{c}_{\boldsymbol{3}}, c_{4}$, and $c_{5}$ are vectors and scalars of coefficients, while $\Pi_{s}$ denotes the measures of the future market profitability, $G_{s}$ political variables, $R_{s}$ regulatory control variables, REGULATION $N_{s}$ is a dummy equal to one if the state is regulated, SFIRMS is the number of firms in the state, and $\eta_{s}$ is an i.i.d. stochastic term.

The empirical implementation of the full model implies the simultaneous estimation of equations (4), (6), and (9) with the varying conduct parameter specified in (7) and the second order condition (8).

\footnotetext{
${ }^{14}$ Recently, a number of theoretical contributions have also accounted for endogenous lobbying formation focusing on the role of market structure as a coordination device (e.g. Mitra, 1999; Pecorino, 1998; Pecorino, 2001; and Hillman et al., 2001 ).
} 


\subsection{Testing the Endogeneity of Lobbying}

In order to assess whether lobbying is endogenous to the market strategies, we perform a Durbin-Wu-Hausman specification test based on artificial regressions. ${ }^{15}$ The basic idea of the original Hausman's (1978) endogeneity test is to contrast two vectors of estimates, one of which is consistent under weaker conditions than the other. Davisdson and McKinnon (1989) develop a more general specification test based on artificial regression. Their procedure consists of testing whether the fitted values of the potentially endogenous variable are correlated with the error term of the equation where the potential endogeneity problem is present. If this is not the case, the least squared estimate of the simple model are consistent.

To clarify how the test is performed, we briefly describe our procedure. We write our model in a slightly different fashion as follows:

$$
\begin{gathered}
P_{m s}=f_{1}\left(X_{m s}^{D}, Q_{m s}, \phi_{1}\right)+\epsilon_{1}, \\
Q_{m s}=f_{2}\left(X_{m s}^{C}, P_{m s}, g\left(L_{s}\right), \phi_{2}\right)+\epsilon_{2}, \\
L_{s}=f_{3}\left(X_{s}^{L}, \phi_{3}\right)+\epsilon_{3},
\end{gathered}
$$

where $X_{s}^{L}$ is a matrix of exogenous variables that influences lobbying decisions, and $\phi_{i}$, $i=1,2,3$ are matrices of parameters. Note that (10) corresponds to (4) and (11) is just a transformation of (6) where we solve for $Q$. We want to test whether $L$ is endogenous. The lobbying equation (12) is estimated by OLS and the fitted values $\widehat{L}$ are computed. We then consider the following artificial regression, where the fitted values of $L$ are inserted in (11) as an additional explanatory variable:

$$
Q_{m s}=f_{2}\left(X_{m s}^{C}, P_{m s}, g\left(L_{s}\right), \phi_{2}\right)+\delta \widehat{L}_{s}+\epsilon_{2}
$$

\footnotetext{
${ }^{15}$ See Davidson and McKinnon (1993) for a general presentation of the DWH test based on artificial regressions.
} 
We finally estimate (12) and (13) simultaneously and test the hypothesis that the parameter $\delta$ is equal to zero. ${ }^{16}$ If the null hypothesis is rejected, one can conclude that lobbying is endogenous and must account for this fact by using the full model as presented in the previous section.

\section{Results}

We estimate the above models applying a full information maximum likelihood (FIML) with normally distributed error terms. ${ }^{17}$ Before comparing the findings from the exogenous and endogenous lobbying models, we shortly discuss a preliminary estimation of the market model with a constant conduct parameter and test behavioral hypotheses.

Table 4 reports the results of the FIML estimation where we impose $\theta_{m s}=1$ for the monopoly period as well as the second order condition (8) in order to enhance efficiency. ${ }^{18}$ The table shows that most of the estimated coefficients in the marginal cost equation are significant and of the expected sign. The effect of quantity is negative and significantly different from zero, which suggests the presence of increasing returns to scale. In the inverse demand equation the per capita income and population density have a significant impact, which is positive as expected. This means, that cellular prices were significantly higher in rich and densely populated metropolitan areas. All other exogenous variables, except YEAR, are also significant and positive. The point estimate for the constant conduct parameter is equal to $0.76 .{ }^{19}$ At the $5 \%$ significance level cartel behavior cannot be rejected, while Cournot-Nash conduct cannot be rejected at the $10 \%$ level. The competitive equilibrium is ruled out at type-I errors of $1 \%$. This result suggests that, on average, firms in the U.S. mobile telecommunications sector behaved more collusively than in a noncooperative duopoly even after the second firm had entered the market. ${ }^{20}$

\footnotetext{
${ }^{16}$ We do not impose the second order condition in order to limit the endogeneity problem to the first order condition equation (6).

${ }^{17}$ See appendix A for details.

${ }^{18}$ As a robustness check, we estimated the same model without imposing the second order condition and ex post verified that it is satisfied.

${ }^{19}$ A similar result was originally obtained by Parker and Röller (1997). The adopted specification is, though, slightly different, which explains the deviations in the point estimates for some of the parameters.

${ }^{20}$ The average firms' conduct appears to be remarkably stable during the sample period: repeating
} 


\subsection{Exogenous Lobbying}

The results from the estimation of the market model where the conduct parameter is a function of exogenous lobbying expenditures are reported in table 5. Qualitatively the new findings reflect those derived from the model with constant conduct even though there are some quantitative differences between the two specifications. While the significance level of all coefficients' estimates does not change, the coefficients are slightly different in the two models.

The central result of this specification pertains to the estimation of the varying conduct parameter. The coefficient of the constant term in the conduct equation $d_{0}$ is significant and positive as expected. Measured by the estimate of $d_{1}$, campaign contributions have no significant impact on conduct. Due to our specification, the lobbying coefficient reported in the table estimates $\partial \widetilde{\theta}_{m s} / \partial L O B B Y_{s}$ and not the marginal effect of campaign contributions on market conduct, $\partial \theta_{m s} / \partial L O B B Y_{s}$. We compute the latter by means of the delta method. Evaluated at the sample mean of $L O B B Y_{s}$, the resulting parameter is equal to -0.0110 with a standard error of 0.0102 . Hence, assuming firms' campaign contributions are exogenous, we do not find a significant impact of these contributions on market conduct.

\subsection{Endogenous Lobbying}

We can now turn to the results from the simultaneous estimation of the full model: the inverse market demand, market supply, and lobbying expenditures including the varying conduct parameter and the second order condition (8). The findings are presented in table 6 . In the marginal cost equation, we observe minor differences in the estimates' size among this and the previous specifications. Again, among cost shifters only RENT and YEAR are significant. As expected, marginal costs have increased with the cost of rental space and decreased during the sample period. The coefficient for quantity is also in this specification negative and significantly different from zero suggesting increasing the estimation of table 4 with four year specific conduct parameters (not displayed here) did not lead to significant differences among them. 
returns to scale. The estimators in the demand equation perform more satisfactory in terms of significance and sign, and they show quantitative but not qualitative differences with respect to those obtained with the exogenous lobbying model. All demand drivers, except YEAR, are significant and positive as expected and as already observed in the previous models.

Also in the endogenous lobbying model, our focus is on the varying conduct parameter. The constant has a positive and significant coefficient. Again, we compute the marginal effect of campaign contributions on conduct by transforming the estimate $d_{1}$ at the sample mean of $L O B B Y_{s}$. The resulting estimate is equal to -0.0151 with a standard deviation of 0.0062 , which is significantly different from zero at the $5 \%$ confidence level. The difference between the exogenous and the endogenous lobbying model in evaluating effect of campaign contributions on conduct is a first evidence that endogeneity of campaign contributions matters. $^{21}$

For the interpretation of our finding that high lobbying expenditures hinder collusive agreements we refer to the theoretical literature. If we assume, based on Bernheim's and Whinston's (1990) multimarket argument, that coordination in the product market improves firms' ability to coordinate their political actions, the observed negative relationship linking product market collusion to the actual lobbying expenditures must be due to the private nature of the contested rent. Interpreted in the light of the rent-seeking literature quoted earlier, the reduction in the number of competing players - which is a consequence of coordination - leads to a lower degree of rent dissipation. Similarly, we would expect such a result from the menu-auction approach, were the auctioneer's profits increase with the level of conflict among the bidders. Coordination can be seen as a device that reduces the firms' heterogeneity in valuations about the feasible political decisions by equalizing their payoffs under alternative regimes. As a result of more homogeneous interests, firms spend less money or effort to avoid policies that, without coordination,

\footnotetext{
${ }^{21}$ Parker and Röller (1997) find that cross-ownership and multimarket contact had a significant impact on market behavior. We check the robustness of our results, by estimating various models, where we control for these and other market structure characteristics in the estimation of conduct. Throughout we find a negative and significant impact of campaign contributions on conduct.
} 
would have weakened their own strategic position relative to their competitors'. In other words, coordination among conflicting parties reduces the costs of buying a particular policy decision.

If, however, fighting regulation were a pure public good for the firms, then a higher degree of coordination would imply greater rent seeking efforts. Hence, the observed relationship between campaign contributions and market conduct must be due to the fact that coordination in lobbying and collusion are negatively related. As pointed out by Ludema (2001) this can be the case when defection in individual lobbying expenditures are observed significantly lagged. This effect, however, relies on the existence of an observational gap, such that any deviation in lobbying is only unveiled one period after the market game has finished..$^{22}$

Pertaining to the lobbying equation, we find that, ceteris paribus, campaign contributions are significantly higher when several firms are present in the market. If regulation is a private good, the empirically established relationship between market structure and lobbying expenditures would imply that firms are not well coordinated and an increase in the number of firms raises total campaign contributions, because each firm spends too much money to protect its private interest. If, however, regulation is perceived to be a public good, this result implies that firms are coordinated in the political market and manage to avoid the free rider problem. We cannot explore this relationship in more depth, given our descriptive approach, however we stress that market structure apparently has an important effect on firms' decision of whether to participate in the political market or not. ${ }^{23}$

In explaining campaign contributions, future market profitability measured by the state's population and, to a lower extent, per-capita income is found to have a strong

\footnotetext{
${ }^{22}$ This limitation substantially reduces the attractiveness of Ludema's point, especially because it is empirically difficult to identify the existence and the length of this observational gap.

${ }^{23}$ There exists an extensive empirical literature concerning the role of market structure on lobbying expenditures. A few studies find that concentration has a positive and significant effect on campaign contributions (e.g. Pittman, 1988), others obtain a negative and significant relationship (Salomon and Siegfried, 1977 and Zardkhooi, 1985 ). The majority, however, do not find any significant effect or mixed results (e.g. Grier et. al., 1991 and Grier and Munger, 1991). See Potters and Sloof (1996) for an excellent survey of the empirical literature on interest groups.
} 
positive impact, which is however significant only for the former variable. The fact that future market profitability seems to be important for the firms tendency to lobby politicians or bureaucrats can be explained with the lag between the payment of campaign contributions and the actual policy decision.

The number of full time employees in the PUC has a negative and significant impact on campaign contributions. A possible interpretation is that larger bureaucratic institutions are more difficult to influence than smaller ones. Thus, large PUCs reduce the degree of efficiency to which firms campaign contributions affect regulatory decisions in the cellular market. Moreover, we show that campaign contributions are higher in states where the salaries of PUC members are high, suggesting high costs of capturing rich officials. Campaign contributions significantly decrease with regulation. This might reflect that the issues firms try to address through lobbying depend on the regulatory regime. Finally, we find that political contributions increase in federal election years echoing the needs of candidates to finance their campaigns.

We analyze the endogeneity of lobbying expenditures by means of a DWH test based on artificial regressions. The null hypothesis of exogeneity to be tested is $\delta=0$ in the model given by the two equations (10) and (13). Since there is only one restriction to test, a simple t-statistic can be used. We estimate the model with different techniques in order to investigate the robustness of our results. For all estimations the null hypothesis is rejected at least at the $10 \%$ significance level. ${ }^{24}$ Hence, campaign contributions are to be considered statistically endogenous with respect to the market game. This important result confirms our view that firms' lobbying decisions and their product market strategies are interdependent. Estimating the effect of campaign contributions on product market conduct without considering that the former are a part of firms profit maximizing strategy, would lead to inconsistent estimates.

\footnotetext{
${ }^{24}$ We used 2SLS, 3SLS, and FIML. The t-statistics for the different models are 1.83, 1.96, and 1.61 with asymptotic p-values of $0.0686,0.0508$, and 0.1085 respectively.
} 


\section{Conclusions}

This paper empirically examines the relationship between product market competition and lobbying expenditures. We apply a structural market model and estimate whether the contributions to the political parties affect market behavior taking into account lobbying endogeneity. Depending on the interrelation between firms' conduct in the underlying market and lobbying games and on the nature of the contested rent, the effect of firms' political activities on their product market conduct can be positive or negative. One of the aims of our study is to analyze the existence and sign of such an effect.

Because of its unique regulatory and market environment, we investigate data from the U.S. mobile telecommunications industry that guarantees enough variation in all relevant dimensions to identify firms' market and political behavior.

In order to estimate market interactions, we adopt the conjectural variations approach, which we have modified to allow for a varying conduct parameter across markets and augmented by the estimation of the endogenous lobbying equation. Since regulatory decisions and campaign contributions are made at the state rather than at the market level, we estimate the lobbying equation using the states as the observation unit, whereas the observation unit for the market game are the Metropolitan Statistical Areas. The different models are estimated by non linear full information maximum likelihood.

In the endogenous lobbying model, we find a strong and significant relationship between our measure of collusion and the industry's campaign contributions. This relation is negative, implying that higher lobbying expenditures foster a more competitive industry. Our interpretation of this result relies on a multimarket contact type of argument, which suggests that lobbying formation acts as a coordination device for product market collusion and vice versa. Under this presumption, the negative relationship between product market conduct and the industry's campaign contributions indicates that the regulation which firms try to influence, is a private good among them.

The second important result of our study is that lobbying expenditures must be considered endogenous. From the empirical point of view, the explicit consideration of lobbying 
endogeneity allows a consistent and unbiased estimation of campaign contributions' effect on market conduct. Moreover, this finding gives empirical support to for the hypothesis that firms not only interact in the product market but are also active in the political market with the aim of influencing the regulatory environment where they operate.

These considerations have important policy implications as well, since ignoring the interaction of political and market activities might misguide the evaluation of competition policy on firms' behavior. Consider the following simplifying example. Assume that the regulatory authority has instruments to successfully fight collusive behavior in order to enhance consumers' welfare. If product market cooperation is positively related to firms' cooperation in the political arena, then a regulatory intervention that reduces collusion will also decrease coordination in lobbying. In the case of a private good type of regulation, this implies an increase in campaign contributions, which amounts to a possible welfare reduction, since lobbying expenditures are partially wasteful. ${ }^{25}$ Similarly, limitations on campaign contributions might have unexpected welfare effects by influencing firms' behavior in the product market.

This paper gives a more comprehensive view of firms' behavior in a regulated industry than shown in the existing empirical literature. A challenging task for future research is the extension of the structural analysis used to model product market interactions to the firms' political behavior. Beyond that, the interactions between firms and policy makers should also be considered in a political economy model of regulation. Thus, a full structural empirical model, where regulation and firms' behavior in the product as well as in the political markets are endogenously considered, seems to be the natural extension of our approach.

\section{References}

Ansolabehere, Stephen, James M. Snyder, and Micky Tripathi, "Are PAC Contributions and Lobbying Linked? New Evidence from the 1995 Lobby Disclosure

\footnotetext{
${ }^{25}$ We thank Johan Lagerlöf for pointing this out.
} 
Act," Business and Politics, 2002, 4, 131-155.

Baron, David, "Integrated Market and Nonmarket Strategies in Client and Interest Group Politics," Business and Politics, 1999, 1, 7-34.

Bernheim, Douglas B. and Michael D. Whinston, "Menu Auctions, Resource Allocation, and Economic Influence," The Quarterly Journal of Economics, 1986, 101, $1-31$.

_ and _ _ "Multimarket Contact and Collusive Behavior," Rand Journal of Economics, 1990, 21, 1-26.

Besley, Timothy and Anne Case, "Unnatural Experiments? Estimating the Incidence of Endogenous Policies," The Economic Journal, 2000, 110, F672-F694.

Bresnahan, Timothy F., "Empirical Studies in Industry with Market Power," in R. Schmalansee and R.D. Willig, eds., Handbook of Industrial Organization, Amsterdam: North-Holland, 1989, pp. 1011-1057.

Damania, Richard and Per G. Fredriksson, "On the Formation of Industry Lobby Groups," Journal of Economic Behavior and Organization, 2000, 41, 315-335.

and __ , "Trade Policy Reform, Endogenous Lobby Group, and Environmental Policy," Journal of Economic Behavior and Organization, 2002, 15, 1-23.

Davidson, Russell and James G. McKinnon, "Testing for Consistency Using Artificial Regressions," Econometric Theory, 1989, 5, 363-384.

and __ Estimation and Inference in Econometrics, Oxford: Oxford University Press, 1993.

Duso, Tomaso, "Lobbying and Regulation in a Political Economy: Evidence from the U.S. Cellular Industry," Public Choice, 2003, forthcoming. 
and Lars-Hendrik Röller, "Endogenous Deregulation: Evidence from OECD Countries," Economics Letters, 2003, forthcoming.

Grier, Kevin B. and Michael C. Munger, "Committee Assignments, Constituent Preferences, and Campaign Contributions," Economic Inquiry, 1991, 29, 24-43.

_ _ _ , and Brian E. Roberts, "The Industrial Organization of Corporate Political Participation," Southern Economic Journal, 1991, 57, 727-738.

Hausman, Jerry A., "Specification Tests in Econometrics," Econometrica, 1978, 46, $1251-1271$.

Hazlett, Thomas W. and Robert J. Michaels, "The Cost of Rent-Seeking: Evidence from Cellular Telephone License Lotteries," Southern Economic Journal, 1993, 59, $425-435$.

Hillman, Arye L., Ngo Van Long, and Antoine Soubeyran, "Protection, Lobbying, and Market Structure," Journal of International Economics, 2001, 54, 383-409.

Katz, Eliakim, Shmule Nitzan, and Jacob Rosenberg, "Rent-seeking for Pure Public Goods," Public Choice, 1990, 65, 49-60.

Ludema, Rodney D., "Market Collusion and the Politics of Protection," European Journal of Political Economy, 2001, 17, 817-833.

Mayo, John W. and Yasuji Otsuka, "Demand Pricing and Regulation: Evidence from the Cable TV Industry," RAND Journal of Economics, 1991, 21, 396-410.

Mitra, Devashish, "Endogenous Lobbying Formation and Endogenous Protection: A Long Run Model of Trade Policy Determination," American Economic Review, 1999, 89, 1116-1134.

Nitzan, Shmuel, "Modelling Rent-seeking Contests," European Journal of Political Economy, 1994, 10, 41-60. 
Parker, Philip and Lars-Hendrik Röller, "Collusive Conduct in Duopolies: Multimarket Contact and Cross-Ownership in the Mobile Telephone Industry," RAND Journal of Economics, 1997, 28, 304-322.

Pecorino, Paul, "Is There a Free Rider Problem in Lobbying? Endogenous Tariffs, Trigger Strtategies, and the Number of Firms," American Economic Review, 1998, $88,652-660$.

, "Market Structure, Tariff Lobbying and the Free-Rider Problem," Public Choice, 2001, 106, 203-220.

Pittman, Russell, "Rent-Seeking and Market Structure," Public Choice, 1988, 58, 173185.

Potters, Jan and Randolph Sloof, "Interest Groups: A Survey of Empirical Models That Try to Assess Their Influence," European Journal of Political Economy, 1996, 12, 403-442.

Salomon, Lester and John Siegfried, "Economic power and Political Influence: The Impact of Industry Structure on Public Policy," American Political Science Review, 1977, 71, 1026-1043.

The Council of State Governments, The Book of the States 1984-1985, Vol. 25, Lexington, Kentucky: The Council of State Governments, 1984.

, The Book of the States 1986-1987, Vol. 26, Lexington, Kentucky: The Council of State Governments, 1986.

, The Book of the States 1988-1989, Vol. 27, Lexington, Kentucky: The Council of State Governments, 1988.

U.S. Bureau of Census, Statistical Abstract of the United States: 1989 (109th Edition), Washington D.C.: U.S. Bureau of Census, 1989. 
Zardkoohi, Asghar, "On the Political Participation of the Firm in the Electoral Process," Southern Economic Journal, 1985, 51, 804-817. 


\section{A The Log-Likelihood Function of the Endogenous Lobbying Model}

The FIML estimation applied in this study matches the specific data structure: policy and lobbying decisions are made at the state level but each state contains an idiosyncratic number of markets, $M_{s} .{ }^{26}$ Denote the vector of residuals for state $s$ with $\varepsilon_{s}$, with $\operatorname{dim}\left(\varepsilon_{s}\right)=2 M_{s}+1$. The residuals are a vector valued function $\mathbf{f}_{s}$ of all endogenous variables $\mathbf{y}_{s}=\left(P_{1 s}, \ldots P_{M_{s} s}, Q_{1 s}, \ldots Q_{M_{s} s}, L_{s}\right)^{\prime}$ and all exogenous variables $\mathbf{x}_{s}$ :

$$
\varepsilon_{s}=\mathbf{f}_{s}\left(\mathbf{y}_{s}, \mathbf{x}_{s}\right)
$$

The log-likelihood of estimating equation (9), $M_{s}$ inverse demand equations (4), and $M_{s}$ quantity setting equations (6) by nonlinear FIML is

$$
l=\text { const }+\sum_{s} \ln \left|\operatorname{det} \mathbf{J}_{s}\right|+\frac{1}{2} \sum_{s} \ln \left(\operatorname{det} \boldsymbol{\Sigma}_{s}^{-1}\right)-\frac{1}{2} \sum_{s} \mathbf{f}_{s}^{\prime} \boldsymbol{\Sigma}_{s}^{-1} \mathbf{f}_{s},
$$

where $\boldsymbol{\Sigma}_{s}$ is the state specific covariance and $\mathbf{J}_{s}=\partial \mathbf{f}_{s} / \partial \mathbf{y}_{s}^{\prime}$. Rewriting $\boldsymbol{\Sigma}_{s}$ yields

$$
\left(\begin{array}{lll}
\Sigma_{P} & \Sigma_{P Q} & \Sigma_{P L} \\
\Sigma_{P Q} & \Sigma_{Q} & \Sigma_{Q L} \\
\Sigma_{P L}^{\prime} & \Sigma_{Q L}^{\prime} & \sigma_{L}
\end{array}\right)
$$

where $\boldsymbol{\Sigma}_{P}$ and $\boldsymbol{\Sigma}_{Q}$ are covariance matrices of the inverse demand and supply equations respectively, while $\sigma_{L}$ denotes the variance of the lobbying equation. The matrices $\boldsymbol{\Sigma}_{P L}$ and $\boldsymbol{\Sigma}_{Q L}$ are the covariances between the market equations and the lobbying equation.

We assume that all markets and all states are independent and that all residuals of a specific type of equation are drawn from the same normal distribution with zero mean and variance $\sigma_{P}, \sigma_{Q}$, and $\sigma_{L}$. Thereby $\boldsymbol{\Sigma}_{P}=\mathbf{1}_{M_{s}} \cdot \sigma_{P}, \boldsymbol{\Sigma}_{Q}=\mathbf{1}_{M_{s}} \cdot \sigma_{Q}$, and $\boldsymbol{\Sigma}_{P Q}=\mathbf{1}_{M_{s}} \cdot \sigma_{P Q}$, where $\mathbf{1}_{M_{s}}$ is a $M_{s}$-dimensional identity matrix and $\sigma_{P Q}$ denotes the covariance between the inverse demand equation and the supply equation in the same market. Furthermore, let the covariance between the market equations and the state equation be such that (I) the general "affinity" of the state equation to a specific type of

\footnotetext{
${ }^{26}$ The estimation abstracts from time effects in the residuals because the panel is too short and too unbalanced. Hence, for convenience, we omit the time subscript in this appendix.
} 
market activity (i.e., demand or supply) within this state is independent of the number of these markets and (II) the covariances between the state equation and all market equations of the same type in this state are equal. Assumption (I) is reflected by $\operatorname{cov}\left(\varepsilon_{L s}, \varepsilon_{P s 1}+\right.$ $\left.\cdots+\varepsilon_{P s M_{s}}\right)=\sigma_{P L}$ and $\operatorname{cov}\left(\varepsilon_{L s}, \varepsilon_{Q s 1}+\cdots+\varepsilon_{Q s M_{s}}\right)=\sigma_{Q L}$ while assumption (II) leads to $\operatorname{cov}\left(\varepsilon_{L s}, \varepsilon_{P s 1}\right)=\cdots=\operatorname{cov}\left(\varepsilon_{L s}, \varepsilon_{P s M_{s}}\right)$ and $\operatorname{cov}\left(\varepsilon_{L s}, \varepsilon_{Q s 1}\right)=\cdots=\operatorname{cov}\left(\varepsilon_{L s}, \varepsilon_{Q s M_{s}}\right)$. This implies that $\operatorname{cov}\left(\varepsilon_{L s}, \varepsilon_{P s m}\right)=1 / M_{s} \sigma_{P L}$ and $\operatorname{cov}\left(\varepsilon_{L s}, \varepsilon_{Q s m}\right)=1 / M_{s} \sigma_{Q L}$ for all markets $m=1, \ldots, M_{s}$. Hence, $\boldsymbol{\Sigma}_{P L}=u_{M_{s}} \cdot \sigma_{P L} / M_{s}$ and $\boldsymbol{\Sigma}_{Q L}=u_{M_{s}} \cdot \sigma_{Q L} / M_{s}$, where $u_{M_{s}}$ is a $M_{s}$-dimensional column vector of ones. With this structure, the correlation between the lobbying equation and the sum of the residuals of the market equations of either type decreases in $M_{s} \cdot{ }^{27}$

\footnotetext{
${ }^{27}$ In a sensitivity check, we imposed $\sigma_{P L}=\sigma_{Q L}=0$. The estimates are qualitatively not affected by this change.
} 


\section{B Tables}

Table 1. Definition of Variables

\begin{tabular}{|c|c|}
\hline Variables & Definition \\
\hline$\overline{\mathrm{p}}$ & 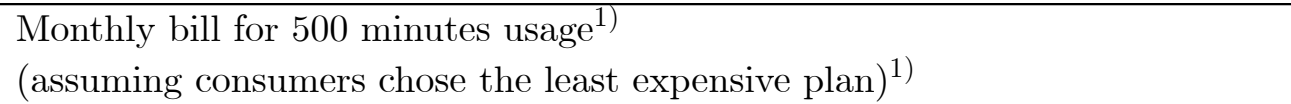 \\
\hline Q & Quantity proxy: Total number of cells in a given network ${ }^{1)}$ \\
\hline TIME & Time trend in months ${ }^{1)}$ \\
\hline POP & Market (MSA) Population in million inhabitants ${ }^{1)}$ \\
\hline INCOME & Market (MSA) annual income per capita in $10.000 \$ 1$ ) \\
\hline BUSINESS & $\begin{array}{l}\text { Number of high-potential business establishments (business, } \\
\text { health care,professional and legal services, contract construction, } \\
\text { transportation, finance,insurance,real estate) divided by } 1000^{1 \text { ) }}\end{array}$ \\
\hline ENERGY & Average monthly cost per square foot of office space (in $\$)^{1)}$ \\
\hline PRIME & One period lagged prime lending rate ${ }^{1)}$ \\
\hline WAGE & Average weekly salary per employee for the cellular industry (in $100 \$)^{1)}$ \\
\hline RENT & Average monthly rent per square foot of office space ${ }^{1)}$ \\
\hline OPERATE & $\begin{array}{l}\text { Average monthly general overhead and operating expenses } \\
\text { per square foot of office space }{ }^{1)}\end{array}$ \\
\hline ENTRY & Dummy $=1$ after the second carrier enters into the market ${ }^{1)}$ \\
\hline SFIRMS & Number of firms operating in state $\mathrm{s}$ at time $\mathrm{t}^{1)}$ \\
\hline REGULATION & Dummy $=1$ if no price regulatory ban was imposed in the market $\left.{ }^{2}\right)$ \\
\hline GOVDEM & Dummy $=1$ if the State's Governor was from the democratic party ${ }^{3)}$ \\
\hline GSALARY & Governor's annual salary in $10.000 \$^{3)}$ \\
\hline PRESELECT & Dummy $=1$ if year of presidential election ${ }^{3)}$ \\
\hline LEGISLELECT & Percentage of the state's legislature that was up for election in a given year ${ }^{3)}$ \\
\hline FEDELECT & Dummy $=1$ if year of federal election (Senate and House) $)^{3)}$ \\
\hline TIGHT & $\begin{array}{l}\text { Absolute value of the \% difference between Republicans' and Democrats' } \\
\text { seats in the state's legislature }{ }^{3)}\end{array}$ \\
\hline PUCMEM & Number of Members the State Public Utility Commission $(\mathrm{PUC})^{3)}$ \\
\hline PUCTERM & Length of term of the PUC members (years $)^{3)}$ \\
\hline PUCSTAFF & Number of full-time employees in the State Public Utility Commission ${ }^{3)}$ \\
\hline PUCSAL & PUC members' annual salary in $10.000 \$ 3$ ) \\
\hline POPSTATE & State Population in million inhabitants $\left.{ }^{3}\right)$ \\
\hline INCSTATE & State annual income per capita in $10.000 \$ 3$ ) \\
\hline LOBBY & Total industry annual campaign contributions in $10.000 \$(\text { without AT\&T) })^{4}$ \\
\hline
\end{tabular}


Table 2. Preliminary Statistics - Market Variables

\begin{tabular}{lrr|rr}
\hline \multirow{2}{*}{ Variable } & \multicolumn{2}{c|}{ Full sample } & \multicolumn{2}{c}{ Aggregated sample } \\
\hline \hline $\mathrm{p}$ & 1.972 & 0.393 & 1.952 & 0.400 \\
$\mathrm{Q}$ & 15.665 & 17.346 & 15.097 & 16.976 \\
TIME & 49.240 & 12.342 & 51.309 & 13.879 \\
POP & 0.186 & 0.266 & 0.172 & 0.251 \\
INCOME & 2.825 & 0.375 & 2.809 & 0.371 \\
DENSITY & 0.502 & 0.398 & 0.479 & 0.372 \\
BUSINESS & 2.247 & 0.413 & 2.226 & 0.426 \\
ENERGY & 1.760 & 0.372 & 1.764 & 0.376 \\
PRIME & 9.456 & 1.107 & 9.363 & 1.150 \\
WAGE & 5.197 & 1.285 & 5.239 & 1.342 \\
RENT & 16.247 & 4.904 & 16.526 & 4.884 \\
OPERATE & 6.704 & 1.683 & 6.622 & 1.688 \\
ENTRY & 0.680 & 0.467 & 0.699 & 0.449 \\
Observations & \multicolumn{3}{c}{478} & \multicolumn{3}{c}{288} \\
\hline
\end{tabular}

Table 3. Preliminary Statistics - Political Variables

\begin{tabular}{lrr}
\hline \multicolumn{1}{c}{ Variable } & Mean & Std. Dev. \\
\hline \hline GOVDEM & 0.619 & 0.487 \\
GSALARY & 7.275 & 1.689 \\
PRESELECT & 0.250 & 0.434 \\
LEGISLELECT & 0.385 & 0.417 \\
FEDELECT & 0.500 & 0.502 \\
TIGHT & 0.315 & 0.236 \\
PUCMEM & 3.988 & 1.336 \\
PUCTERM & 5.456 & 1.181 \\
PUCSTAFF & 209.394 & 201.180 \\
PUCSALARY & 5.549 & 1.347 \\
POPSTATE & 0.562 & 0.533 \\
INCSTATE & 1.309 & 0.251 \\
LOBBY & 3.150 & 2.881 \\
REGULATION & 0.500 & 0.502 \\
SFIRMS & 2.550 & 1.120 \\
Observations & & \\
\hline
\end{tabular}


Table 4. Market Model - Constant Conduct Parameter

\begin{tabular}{|c|c|c|c|}
\hline & Coefficient & d. Err. & \\
\hline \multicolumn{4}{|l|}{ Marginal Cost } \\
\hline constant & 1.2518 & 0.2162 & $* * *$ \\
\hline Q & -0.0027 & 0.0010 & $* *$ \\
\hline ENERGY & -0.0138 & 0.0426 & \\
\hline WAGE & 0.0101 & 0.0144 & \\
\hline RENT & 0.0291 & 0.0052 & $* * *$ \\
\hline YEAR & -0.0776 & 0.0230 & $* * *$ \\
\hline \multicolumn{4}{|l|}{ Inverse Demand } \\
\hline constant & 1.5953 & 0.2317 & $* * *$ \\
\hline POP & 1.4173 & 0.3394 & $* * *$ \\
\hline BUSINESS & 0.0837 & 0.0427 & $* *$ \\
\hline DENSITY & 0.3152 & 0.0980 & $* * *$ \\
\hline INCOME & 0.2552 & 0.0792 & $* * *$ \\
\hline YEAR & 0.0648 & 0.0440 & \\
\hline \multicolumn{4}{|l|}{ Second Order Condition } \\
\hline $\mathrm{e}$ & -0.6647 & 0.2462 & \\
\hline \multicolumn{4}{|l|}{ Conduct Parameter } \\
\hline$\theta_{m s}$ & 0.7635 & 0.0985 & $* * *$ \\
\hline Test for Cournot $(\theta=0.5)^{a}$ & \multicolumn{2}{|l|}{2.675} & $*$ \\
\hline Test for Cartel $(\theta=1)^{a}$ & \multicolumn{2}{|l|}{-2.401} & $* *$ \\
\hline
\end{tabular}


Table 5. Market Model - Variable Conduct Parameter Exogenous Lobbying

\begin{tabular}{lrrl}
\hline & Coefficient & Std. Err. & \\
\hline \hline Marginal Cost & & & \\
constant & 1.2366 & 0.2212 & $* * *$ \\
Q & -0.0024 & 0.0010 & $* *$ \\
ENERGY & -0.0164 & 0.0428 & \\
WAGE & 0.0106 & 0.0142 & \\
RENT & 0.0294 & 0.0054 & $* * *$ \\
YEAR & -0.0714 & 0.0242 & $* * *$ \\
Inverse Demand & & & \\
constant & & & \\
POP & 1.6069 & 0.2276 & $* * *$ \\
BUSINESS & 1.3798 & 0.3323 & $* * *$ \\
INCOME & 0.0867 & 0.0425 & $* *$ \\
DENSITY & 0.3086 & 0.0963 & $* * *$ \\
YEAR & 0.2601 & 0.0807 & $* * *$ \\
Second Order Condition & 0.0635 & 0.0442 & \\
e & & & \\
Conduct Parameter & -0.6656 & 0.2482 & $* * *$ \\
constant & & & \\
LOBBY & & & $* * *$ \\
\hline
\end{tabular}

FIML estimates; 288 Observations; Second order condition (8) imposed; $* *$ and $* *$ denotes significance at th $1 \%$ and $5 \%$ levels respectively. 
Table 6. Full Model - Variable Conduct Parameter Endogenous Lobbying

\begin{tabular}{|c|c|c|c|}
\hline & Coefficient & td. Err. & \\
\hline \multicolumn{4}{|l|}{ Marginal Cost } \\
\hline constant & 1.2080 & 0.1820 & $* * *$ \\
\hline Q & -0.0021 & 0.0010 & $* *$ \\
\hline ENERGY & -0.0198 & 0.0451 & \\
\hline WAGE & 0.0096 & 0.0130 & \\
\hline RENT & 0.0301 & 0.0047 & $* * *$ \\
\hline YEAR & -0.0718 & 0.0220 & $* * *$ \\
\hline \multicolumn{4}{|l|}{ Inverse Demand } \\
\hline constant & 1.5568 & 0.2225 & $* * *$ \\
\hline POP & 1.4617 & 0.3256 & $* * *$ \\
\hline BUSINESS & 0.0950 & 0.0528 & * \\
\hline INCOME & 0.3276 & 0.0897 & $* * *$ \\
\hline DENSITY & 0.2601 & 0.0894 & $* * *$ \\
\hline YEAR & 0.0704 & 0.0388 & \\
\hline \multicolumn{4}{|c|}{ Second Order Condition } \\
\hline e & -0.6167 & 0.1992 & $* * *$ \\
\hline \multicolumn{4}{|c|}{ Conduct Parameter } \\
\hline constant & 1.4225 & 0.5457 & $* * *$ \\
\hline LOBBY & -0.0833 & 0.0420 & $* *$ \\
\hline \multicolumn{4}{|c|}{ Lobbying Equation } \\
\hline constant & -2.8111 & 1.4060 & $* *$ \\
\hline GOVDEM & 0.0197 & 0.3386 & \\
\hline GSALARY & -0.1492 & 0.1597 & \\
\hline PUCTERM & -0.0271 & 0.1501 & \\
\hline PUCSTAFF & -0.3209 & 0.1489 & $* *$ \\
\hline PUCSAL & 0.4944 & 0.2246 & $* *$ \\
\hline POP_STATE & 3.3490 & 0.5282 & $* * *$ \\
\hline INC_STATE & 1.0598 & 0.8271 & \\
\hline 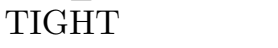 & -0.8366 & 0.8423 & \\
\hline FEDELECTION & 1.9177 & 0.3364 & $* * *$ \\
\hline REGULATION & -0.8161 & 0.3441 & $* *$ \\
\hline SFIRMS & 0.6454 & 0.1661 & $* * *$ \\
\hline
\end{tabular}

FIML estimates; 288 market and 125 state observations; Second order condition (8) is imposed; $* * *$ and $* *$ denote significance at the 1 and $5 \%$ levels respectively. 
Bücher des Forschungsschwerpunkts Markt und politische Ökonomie

Books of the Research Area Markets and Political Economy

Andreas Stephan

Essays on the Contribution of Public Infrastructure to Private: Production and its Political

Economy

2002, dissertation.de

Hans Mewis

Essays on Herd Behavior and Strategic

Delegation

2001, Shaker Verlag

Andreas Moerke

Organisationslernen über Netzwerke - Die

personellen Verflechtungen von

Führungsgremien japanischer

Aktiengesellschaften

2001, Deutscher Universitäts-Verlag

Silke Neubauer

Multimarket Contact and Organizational Design

2001, Deutscher Universitäts-Verlag

Lars-Hendrik Röller, Christian Wey (Eds.)

Die Soziale Marktwirtschaft in der neuen

Weltwirtschaft, WZB Jahrbuch 2001

2001, edition sigma

Michael Tröge

Competition in Credit Markets: A Theoretic

Analysis

2001, Deutscher Universitäts-Verlag

Tobias Miarka

Financial Intermediation and Deregulation:

A Critical Analysis of Japanese Bank-Firm-

Relationships

2000, Physica-Verlag

Rita Zobel

Beschäftigungsveränderungen und organisationales Lernen in japanischen Industriengesellschaften

2000, Humboldt-Universität zu Berlin

http://dochost.rz.hu-berlin.de/dissertationen/zobel-

rita-2000-06-19

Jos Jansen

Essays on Incentives in Regulation and Innovation

2000, Tilburg University

Ralph Siebert

Innovation, Research Joint Ventures, and

Multiproduct Competition

2000, Humboldt-Universität zu Berlin

http://dochost.rz.hu-berlin.de/dissertationen/siebert-

ralph-2000-03-23/

Damien J. Neven, Lars-Hendrik Röller (Eds.)

The Political Economy of Industrial Policy in

Europe and the Member States

2000, edition sigma
Jianping Yang

Bankbeziehungen deutscher Unternehmen: Investitionsverhalten und Risikoanalyse 2000, Deutscher Universitäts-Verlag

Christoph Schenk

Cooperation between Competitors -

Subcontracting and the Influence of Information, Production and Capacity on Market Structure and Competition

1999, Humboldt-Universität zu Berlin

http://dochost.rz.hu-berlin.de/dissertationen/schenk-

christoph-1999-11-16

Horst Albach, Ulrike Görtzen, Rita Zobel (Eds.)

Information Processing as a Competitive

Advantage of Japanese Firms

1999, edition sigma

Dieter Köster

Wettbewerb in Netzproduktmärkten

1999, Deutscher Universitäts-Verlag

Christian Wey

Marktorganisation durch Standardisierung: Ein

Beitrag zur Neuen Institutionenökonomik des

Marktes

1999, edition sigma

Horst Albach, Meinolf Dierkes, Ariane Berthoin Antal, Kristina Vaillant (Hg.)

Organisationslernen - institutionelle und

kulturelle Dimensionen

WZB-Jahrbuch 1998

1998, edition sigma

Lars Bergman, Chris Doyle, Jordi Gual, Lars

Hultkrantz, Damien Neven, Lars-Hendrik Röller,

Leonard Waverman

Europe's Network Industries: Conflicting

Priorities - Telecommunications

Monitoring European Deregulation 1

1998, Centre for Economic Policy Research

Manfred Fleischer

The Inefficiency Trap

Strategy Failure in the

German Machine Tool Industry

1997, edition sigma

Christian Göseke

Information Gathering and Dissemination

The Contribution of JETRO to

Japanese Competitiveness

1997, Deutscher Universitäts-Verlag 
Fredrik Andersson

Kai A. Konrad

Andreas Stephan

Tomaso Duso

Steffen Huck

Kai A. Konrad

Wieland Müller

Steffen Huck

Kai A. Konrad

Wieland Müller

Jos Jansen

Astrid Jung

Jonas Björnerstedt Johan Stennek

Manfred Fleischer

Karl Wärneryd

Karl Wärneryd

Steffen Huck

Kai A. Konrad

Michal Grajek

Achim Kemmerling

Andreas Stephan

Suchan Chae

Paul Heidhues

Kai A. Konrad Harald Künemund Kjell Erik Lommerud Julio R. Robledo

Tomaso Duso Lars-Hendrik Röller
Globalization and Human Capital Formation

FS IV $01-01$

Regional Infrastructure Policy and its Impact

FS IV $01-02$ on Productivity: A Comparison of Germany and France

Lobbying and Regulation in a Political Economy: FS IV $01-03$ Evidence from the US Cellular Industry

Merger and Collusion in Contest

FS IV $01-04$

Profitable Horizontal Mergers without Cost

Advantages: The Role of Internal Organization,

Information, and Market Structure

Strategic Information Revelation and Revenue

Sharing in an R\&D Race

(A revision of FS IV 99-11)

FS IV $01-05$

FS IV $01-06$

FS IV $01-07$

Complements?

Bilateral Oligopoly

FS IV $01-08$

Regulierungswettbewerb und Innovation in der chemischen Industrie

FS IV $01-09$

FS IV $01-10$

Preference Adaptation in Winner-Take-All Markets

Information in Conflicts

FS IV $01-11$

FS IV $01-12$

Merger Profitability and Trade Policy

Gender Pay Gap in Poland

FS IV $01-13$

FS IV $01-14$

The Contribution of Local Public Infra-structure to Private Productivity and its Political-Economy: Evidence from a Panel of Large German Cities

Nash Bargaining Solution with Coalitions and the Joint Bargaining Paradox

Geography of the Family

FS IV $01-15$

FS IV $01-16$

Towards a Political Economy of Industrial OrganFS IV $01-17$ ization: Empirical Regularities from Deregulation 
Kai A. Konrad

Roman Inderst Christian Wey

Kai A. Konrad

Helmut Seitz

Klaus Gugler Dennis C. Mueller B. Burcin Yurtoglu Christine Zulehner

Kjell Erik Lommerud Odd Rune Straume Lars Sørgard

Andreas Blume Paul Heidhues

Roman Inders Christian Wey

Klaus Gugler Dennis C. Mueller B. Burcin Yurtoglu

Sven-Olof Fridolfsson Johan Stennek
Investment in the Absence of Property Rights - The Role of Incumbency Advantages

Bargaining, Mergers, and Technology Choice in Bilaterally Oligopolistic Industries

Fiscal Federalism and Risk Sharing in Germany: The Role of Size Differences

The Effects of Mergers: An International Comparison

Downstream Merger with Oligopolistic Input FS IV 01-22 Suppliers

Tacit Collusion in Repeated Auctions

The Incentives for Takeover in Oligopoly

Corporate Governance, Capital Market Discipline and the Returns on Investment

Why Mergers Reduce Profits and Raise Share Prices: A Theory of Preemptive Mergers
FS IV $01-23$

FS IV $01-24$

FS IV $01-18$

FS IV $01-19$

FS IV $01-20$

FS IV $01-21$

FS IV $01-25$

FS IV $01-26$ 
Fredrik Andersson

Kai A. Konrad

Lars-Hendrik Röller

Christian Wey

Talat Mahmood Klaus Schömann

Jos Jansen

Jos Jansen

Günter Franke Harris Schlesinger Richard C. Stapleton

Tomaso Duso

Johan Lagerlöf

Paul Heidhues

Olivier Cadot Lars-Hendrik Röller Andreas Stephan

Justus Haucap

Christian Wey

Heidrun C. Hoppe Emre Ozdenoren

Rainer Nitsche

Daniel Krähmer

J. Peter Murmann

Kai A. Konrad

Robert Nuscheler

Fredrik Andersson

Kai A. Konrad Jan Boone
Human Capital Investment and Globalization in Extortionary States

Merger Control in the New Economy

Die Determinanten der Mirgrationsentscheidung von IT-Hochschulabsolventen aus Pakistan Empirische Befunde zur Ausgestaltung der deutschen „Green Card“

The Effects of Disclosure Regulation on Innovative Firms: Common Values

The Effects of Disclosure Regulation on Innovative Firms: Private Values

Multiplicative Background Risk

On the Politics of the Regulatory Reform: Econometric Evidence from the OECD Countries

On the Desirability of an Efficiency Defense in Merger Control

Contribution to Productivity or Pork Barrel? The Two Faces of Infrastructure Investment

Unionization Structures and Firms' Incentives for Productivity Enhancing Investments

Intermediation in Innovation

On the Effectiveness of Anti-Predation Rules

Entry and Experimentation in

Oligopolistic Markets for Experience Goods

The Coevolution of Industries and National Institutions: Theory and Evidence

Terrorism and the State

Physician Reimbursement, Time-Consistency and the Quality of Care

Taxation and Education Investment in the Tertiary Sector

'Be nice, unless it pays to fight': A New Theory of Price Determination with Implications for Competition Policy
FS IV $02-11$

FS IV $02-15$

\author{
FS IV $02-02$ \\ FS IV $02-06$ \\ FS IV $02-01$ \\ FS IV $02-03$ \\ FS IV $02-04$ \\ FS IV $02-05$
}

FS IV $02-07$

FS IV $02-08$

FS IV $02-09$

FS IV $02-10$

FS IV $02-12$

FS IV $02-13$

FS IV $02-14$

FS IV $02-16$

FS IV $02-17$

FS IV $02-18$ 
Kai A. Konrad

Helmut Bester

Kai A. Konrad

Kjell Erik Lommerud

Bjørn Sandvik

Odd Rune Straume

Steffen Huck

Vicki Knoblauch

Wieland Müller

Ralph Siebert

Jürgen Bracht

Saul Lach

Eyal Winter

Steffen Huck

Kai A. Konrad

Daniel Krähmer

Thomas Knaus

Robert Nuscheler

Kurt R. Brekke

Robert Nuscheler

Odd Rune Straume

Kai A. Konrad

Sebastian Kessing

Sebastian Kessing

Michal Grajek

Robert M. Adams Lars-Hendrik Röller Robin C. Sickles

Tomaso Duso

Damien J. Neven Lars-Hendrik Röller

Tomaso Duso Astrid Jung
Altruism and Envy in Contests:

FS IV $02-19$

An Evolutionarily Stable Symbiosis

Delay in Contests

FS IV $02-20$

Good Jobs, Bad Jobs and Redistribution

FS IV $02-21$

On the Profitability of Collusion in Location Games

FS IV $02-22$

Learning by Doing and Multiproduction Effects

FS IV $02-23$

over the Life Cycle: Evidence from the

Semiconductor Industry

Modeling Oligopolistic Price Adjustment in Micro

FS IV $02-24$

Level Panel Data

Strategic Trade Policy and the Home Bias in Firm

Ownership Structure

Delegation versus Authority

FS IV $02-26$

Incomplete Risk Adjustment and Adverse

FS IV $02-27$

Selection in the German Public Health Insurance System

Quality and Location Choices under Price

Regulation

FS IV $02-28$

Inverse Campaigning

FS IV $02-29$

A Note on the Determinants of Labour Share

FS IV $02-30$ Movements

Employment Protection and Product Market Competition

FS IV $02-31$

FS IV $02-32$

Identification of Network Externalities in Markets for Non-Durables

Market Power in Outputs and Inputs: An Empirical Application to Banking

FS IV $02-33$

The Political Economy of European Merger

FS IV $02-34$

Control: Evidence using Stock Market Data

FS IV $02-35$

Market Conduct and Endogenous Lobbying:

Evidence from the U.S. Mobile

Telecommunications Industry 
Bei Ihren Bestellungen von WZB-Papers schicken

Sie bitte unbedingt einen an Sie adressierten Auf-

kleber mit sowie je paper eine Briefmarke im Wert

von 0,51 Euro oder einen "Coupon Reponse Inter-

national " (für Besteller aus dem Ausland)
Please send a self addressed label and postage stamps in the amount of 0.51 Euro or a "CouponReponse International" (if you are ordering from outside Germany) for each WZB-paper requested

Absender / Return Address:

Wissenschaftszentrum Berlin

für Sozialforschung

Presse- und informationsreferat

Reichpietschufer 50

D-10785 Berlin-Tiergarten

Hiermit bestelle ich folgende(s)

Discussion paper(s):

Please send me the following Discussion paper(s):

Bestell-Nr. / Order no.

Autor/in, Kurztitel /Author(s) / Title(s) in brief 